\title{
It's Not What They Do, It's Why They Do It: Employee Motivations in the Study of Work-Life Practices
}

\begin{abstract}
The current study aims to understand why employees' use of home-based telework and part-time work is not consistently linked to intended employee outcomes, in particular lower work-life conflict, lower life-work conflict, more job satisfaction and better job performance. We propose an approach wherein the focus lies on motivational conditions under which employees do or do not make use of work-life practices. Specifically, we argue that two motivational dimensions explain outcome variability within both the group of users and the group of non-users, namely (1) preferences for a certain practice (i.e., the extent to which employees prefer to use or to not use that practice) and (2) perceived pressures (i.e., the extent to which employees experience pressures from the work environment or from their private life to use or to not use a practice). The relevance of these two dimensions is examined using survey data with 382 Flemish employees. We contribute to the literature by challenging the dichotomy between users and non-users and by highlighting the importance of preferences and pressures from two different life spheres. By taking preferences for and pressures affecting practice use into account, the potential difference between employees' wants and needs is emphasized.
\end{abstract}

\section{Keywords:}

Work-life practices; work-life conflict; telework; part-time work; motivation; preferences; perceived pressures 


\section{INTRODUCTION}

Literature on employees' challenge to combine work with private life is emerging quickly. The increased popularity of this topic can be linked to the rise of both single-parent and dual earner families, and changing societal norms concerning work and gender roles (Butts, Casper \& Yang, 2013; Hammer, Colton, Caubet \& Brockwood, 2002; Kossek \& Ruderman, 2012; Neal \& Hammer, 2007). Due to these trends, a growing number of employees today has to combine work roles with other life roles (Greenhaus \& Powell, 2003; Kalliath \& Brough, 2008). Accordingly, organizations increasingly offer work-life practices to their employees (Beauregard \& Henry, 2009; Thompson, Beauvais, \& Lyness, 1999). These are practices which are designed to help employees combine their work with other life roles (Kossek, Lewis \& Hammer, 2010). They include alternative work arrangements regarding flexibility (e.g., home-based telework) and regarding work-time reduction (e.g., part-time work).

Work-life practices are expected to facilitate the combination of work and private life and are therefore believed to increase employees' work attitudes and performance (Hammer, Neal, Newsom, Brockwood \& Colton, 2005). In particular, it is assumed that employees who make use of work-life practices will experience less work-life conflict (i.e., work interfering with private life) and less life-work conflict (i.e., private life interfering with work), which may in turn lead to improved work attitudes and performance (Van De Voorde, Paauwe \& Van Veldhoven, 2012). Yet, to date, research on work-life practices shows inconsistent results concerning the link between the use of work-life practices and these intended outcomes. For instance, while some studies find reducing effects of practice use on conflict measures (Butts et al. 2013), others find no effect or even a conflict enhancing effect (Hammer et al. 2005). Besides, whereas some studies have found moderate links between, on the one hand, the use of work-life practices and, on the other hand, job satisfaction (Butts et al. 2013; Ryan \& 
Kossek, 2008) and performance (Gajendran \& Harrison, 2007; Huselid, 1995), other studies found no effect (Casper \& Harris, 2008) or even a negative one (Kossek \& Ozeki, 1999).

These observed inconsistencies in outcomes of work-life practice use lie at the core of our study. To date, research on the effects of work-life practices mainly focus on how users differ from non-users in terms of conflict, work attitudes and performance outcomes. We argue that this dichotomous classification between users and non-users of work-life practices attenuates variance and posit that it is not whether employees use a specific work-life practice, but rather why they use or not use it (i.e., cognitive conditions accompanying use or non-use of these practices) that explains their conflict, work attitudes and performance outcomes. We thus expect that there are important motivational differences within the group of users and within the group of non-users which explain differences in conflict, work attitudes and performance outcomes.

We specifically focus on two motivation-related dimensions. The first dimension concerns employees' preferences to use or not use a specific work-life practice. To the best of our knowledge, employees' preference for use or non-use of work-life practices has not yet been included in research on work-life practices to date; however, there is ample evidence from other research domains that being in a situation which is in accordance with one's own preferences and, relatedly, having an intrinsic motivation for the situation one is in, strongly influences work attitudes and performance outcomes (e.g., Boon et al., 2011; Gagné \& Deci, 2005; Kossek \& Ruderman, 2012; Kristof-Brown \& Jansen, 2007). The second dimension concerns the pressures people experience to either use or not use a specific work-life practice. It is widely known that employees' decisions at work are often affected by pressures from their social context, both at work and at home (Poelmans, 2005). This is also the case for the use of work-life practices. For instance, the work context might pressure employees towards using telework (i.e., saving desk space) or part-time work (i.e., saving on employee costs to 
prevent down-sizing), or towards not using telework (i.e., bureaucratic control) or not using part-time work (i.e., cost efficiency of full-time personnel). In addition, employees may feel pressured by their private context to either make use of telework or part-time work (i.e., to facilitate household or childcare) or to not make use of these practices (i.e., no optimal working environment or financial pressures respectively). When employees experience such external pressures, irrespective of their actual use or non-use, they are likely to feel less in control of and to feel less discretion over their use or non-use of work-life practices and this could harm their work attitudes and performance (Gagné \& Deci, 2005). Research has already shown the importance of perceived control and discretion at work for many work attitudes and performance outcomes (e.g., Thompson \& Prottas, 2006) and it has also been suggested as an important dimension in the domain of work-life policy use (Kossek, Lautch \& Eaton, 2006); yet, it has rarely been included in studies on work-life practices so far.

We thus argue that it is not the use of work-life practices that affects employee outcomes, but rather cognitive conditions accompanying use or non-use of these practices. These conditions include (1) the extent to which employees' preference for use or non-use of a specific work-life practice fits with their actual use or non-use of that practice, and (2) the extent to which employees experience pressures to use or not use a practice. Our theorizing shifts away from the dichotomous classification of users versus non-users of work-life practices and instead focusses on motivational aspects of use and non-use. In doing so, we acknowledge the difference between on the one hand employees' wants (i.e., preferences), and on the other hand their needs (i.e., perceived pressures). Taking into account preferences and placing practice use in its social context of both the work and the private environment is likely to render the effects of work-life practices more understandable. A clearer understanding of why use of work-life practices does not always lead to positive outcomes could help practitioners to design better work-life strategies. If outcomes depend on 
employees' preferences and perceived pressures, organizations might profit from tailor-made support programs that help employees to reach a good fit between their working conditions and their preferences, and/or to manage external pressures they experience. Enabling employees to make choices according to their preferences and asserting them more control over working conditions might then optimize the effects of offered work-life practices.

Hypotheses will be tested using survey data of 382 employees of a middle-large Belgian university. We test our hypotheses for one specific flexibility practice, i.e., home-based telework, and for one specific work-time reduction practice, i.e., part-time work. We include both a flexibility and work-time reduction practice since each type of practices provides employees with a different resource (i.e., flexibility and time, respectively) and may therefore function differently (Schooreel \& Verbruggen, 2015). We opted for specific practices since it has been argued that different practices serve different functions and should therefore be studied separately (Kelly et al., 2008; Saltzstein, Ting \& Saltzstein, 2001; Schooreel \& Verbruggen, 2015). Finally, we opted specifically for home-based telework and part-time work since for these practices, the actual use can be easily differentiated from the mere availability or sporadic use, which is more difficult for some other practices such as flexible working hours. In addition, these practices are offered often nowadays, which facilitates further study.

\section{USE OF WORK-LIFE PRACTICES: MIXED RESULTS}

Although work-life practices are designed to reduce employees' conflict between work and private life and could in that way increase positive work attitudes and performance outcomes, research up till now does not show consistent links between use of work-life practices and these intended outcomes. Inconsistencies have been found for both the link between practice use and conflict measures and for the link between practice use and work attitudes and performance. 
Firstly, the link between use of work-life practices and conflict outcomes remains unclear (e.g., Shockley \& Allen, 2007; for a meta-analysis, see Kelly et al., 2008). While some studies found the expected reducing effects of work-life practice use on work-life conflict and/or lifework conflict (e.g., Anderson, Coffey \& Byerly, 2002; Hammer, Allen \& Grigsby, 1997), others found no link between them (Henz \& Mills, 2014; for a review, see Beauregard \& Henry, 2009) and still others even found practices to increase conflict (Glass \& Finley, 2002; Hammer et al. 2005; Hill, Ferris \& Martinson, 2003; Raghuram \& Wiesenfeld, 2004; Schieman \& Young, 2010). Also the meta-analytic evidence is inconsistent, with one metaanalysis finding a small negative effect of work-life practices on conflict outcomes (Byron, 2005), while another meta-analysis found no relation between them (Mesmer-Magnus \& Viswesvaran, 2006). Furthermore, other meta-studies emphasize that if studies find effects of work-life practices on conflict outcomes, effect sizes are very small (Allen, Johnson, Kiburz \& Shockley, 2013; Gajendran \& Harrison, 2007).

Secondly, also the (in)direct link between the use of work-life practices and work attitudes and performance outcomes remains unclear. Whereas some cross-sectional studies found moderate links between the use of work-life practices and work attitudes such as job satisfaction (Butts et al., 2013; Ryan \& Kossek, 2008), others found no effects (Casper \& Harris, 2008) and also no effects were found by Hammer and colleagues (2005) in their longitudinal model. Concerning the link between work-life practices and performance, some research found a positive effect of work-life practice use on performance (e.g., Gajendran \& Harrison, 2007; Huselid, 1995), yet other studies show no effect and others a negative effect of practice use on performance (e.g., Hartman, Stoner, \& Arora, 1991; Kossek \& Ozeki, 1999; for a meta-analysis, see Beauregard \& Henry, 2009). In addition, Kelly and colleagues (2008) point out the overall lack of studies that investigate the link between work-life practices and performance outcomes. 
These inconsistencies stimulated researchers to examine the link between work-life practices and conflict, work attitudes and performance outcomes in a more fine-grained way. Research to date has done this in two main ways. First, several studies have distinguished between specific work-life practices and found indeed that different practices had different effects on conflict (Allen et al., 2010) and work attitudes (e.g., Saltzstein et al., 2001). For instance, Kossek and colleagues (2006) showed that telework did not affect conflict outcomes, while job control did, and Saltzstein and colleagues (2001) found that home-based telework was positively correlated with job satisfaction, whereas part-time work was not correlated with job satisfaction and a compressed schedule was related negatively with this work attitude. These results highlight the importance to differentiate between practices, which has been suggested by other scholars as well (e.g., Kelly et al., 2008; Saltzstein et. al, 2001; Schooreel \& Verbruggen, 2015).

Second, some studies also showed the importance of moderating factors affecting the link between work-life practice use and intended outcomes. For example, the expected positive effect of home-based telework on job satisfaction has been found to be lower or even absent when employees experience high family demands (Hill, Miller, Weiner \& Colihan, 1998; Saltzstein et al., 2001) and employees with more parental responsibilities have been found to benefit more from work-life practices than employees with less parental responsibilities (e.g., Byron, 2005; for a meta-analysis, see Allen et al., 2013). Overall, these studies show that focusing on the mere use of work-life practices is insufficient to understand differences in employees' work-life or life-work conflict, work attitudes and performance outcomes and that a more nuanced approach is needed to capture the complexity of this issue.

In this study, we aim to further our understanding of why the use of work-life practices is not consistently linked to intended outcomes by taking a partly different approach. We follow earlier studies by focusing on two specific work-life practices, i.e., home-based telework and 
part-time work. We add to the current approaches, however, by arguing that the complexity of this issue cannot by captured by the dichotomous classification between users and non-users which is traditionally used in studies on work-life practice use (Kossek et al., 2005) and instead propose to focus on motivational conditions accompanying the use or non-use of these practices.

\section{CHALLENGING THE DICHOTOMY OF USERS VERSUS NON-USERS: INCLUDING MOTIVATIONAL ASPECTS}

In this study, we argue that variation in employee outcomes can be better understood by looking at motivational differences accompanying the use and non-use of work-life practices rather than by comparing users with non-users. We therefore propose to abandon the traditional dichotomy between users and non-users and this for two main reasons. First, this dichotomy is not in line with the arguments presented in these studies for expecting positive effects of work-life practice use. These arguments generally focus on how the use of work-life practices can help an employee to facilitate the combination of work with private life. This argument thus expects a reduction in work-life conflict or life-work conflict within an employee (i.e., when comparing the situation of this employee before and after he or she started using the practice); however, it does not imply that employees who make use of worklife practices will experience lower conflict than employees who do not make use of these practices - whereas this is the implicit assumption in a statistical analysis that compares users with non-users. Second, and more importantly for this study, the dichotomy between users and non-users ignores - as we will argue further - important motivational differences within the group of users and within the group of non-users. These differences may account for differences in conflict, work attitudes and performance outcomes.

In this study, we therefore abandon the dichotomy between users and non-users and instead focus on two cognitive conditions accompanying the use or non-use of work-life 
practices: (1) people's preferences for the use or non-use of a specific work-life practice, and (2) the extent to which they experience external pressure from either the work environment or from one's private life to make use or not make use of work-life practices. In what follows, we explain these dimensions and develop hypotheses for their impact on employees' conflict, work attitudes and performance outcomes.

\section{Preferences}

The first dimension concerns employees' preferences for either use or non-use of worklife practices. More specifically, we argue that the fit between a person's own preference for either use or non-use of a work-life practice and their actual use or non-use will be important. The importance of a fit between preferred and actual working conditions has been put central in the self-determination theory of work (Deci \& Ryan, 2000; Gagné \& Deci, 2005). This theory argues that when people are in a situation that is in line with their preferences, basic psychological needs (i.e., the need for competence, the need for relatedness, and the need for autonomy) are satisfied. Fulfillment of these needs facilitates the attainment of intrinsic and autonomous motivation, which may in turn lead to positive work attitudes and well-being (Deci \& Vansteenkiste, 2004; Gagné \& Deci, 2005).

The highly motivating impact of fit between preferences for a certain working situation and the actual working situation has been shown in several domains. For instance, a misfit between preferences for certain job characteristics and actual job characteristic has been linked to negative work attitudes and performance outcomes (Boon, Den Hartog, Boselie \& Paauwe, 2011; Kristof-Brown, Zimmerman \& Johnson, 2005). In addition, in literature on work-life boundary management styles (i.e., strategies employees use to either segment or integrate work and private life), it has been found that rather than the specific boundary management style, it is the fit between the preferred style and the actually enacted style that accounts for work attitudes (Kossek, Ruderman, Braddy \& Hannum, 2012; Kreiner, 2006). 
To date, the importance of individual preferences for work-life practices has not been explicitly addressed in research on the effects of work-life practices. However, there are several indications in the literature that individuals may indeed differ in their preferences for using specific work-life practices. For instance, research on work-life boundary management styles has shown that employees differ in their preference to either segment or integrate boundaries between work and private life (Kossek et al., 2012). As some work-life practices such as home-based telework blur the boundaries between work and private life, it seems logical that also people's preferences for the use of these work-life practice are variable across employees. Relatedly, Standen, Daniels and Lamond (1999) emphasized to include individual differences in preferences for telework and Demerouti, Derks, ten Brummelhuis and Bakker (2014) suggested to include individual differences in preferences for the specific work-life practice enhanced control over one's work schedule.

Building on the above, we expect that employees are likely to differ in their preferences to use or not use a specific work-life practice and that it is the degree of fit or misfit between their preferences and their actual use or non-use of that specific work-life practice which affects their conflict, work attitudes and performance outcomes. Applying this to home-based telework and part-time work, we hypothesize:

Hypothesis 1. Better fit between people's preference for use or non-use of home-based telework and their actual use or non-use of home-based telework will lead to lower worklife conflict (Hypothesis 1a), lower life-work conflict (Hypothesis 1b), higher job satisfaction (Hypothesis 1c), and higher job performance (Hypothesis 1d).

Hypothesis 2. Better fit between people's preference for use or non-use of part-time work and their actual use or non-use of part-time work will lead to lower work-life conflict (Hypothesis 2a), lower life-work conflict (Hypothesis 2b), higher job satisfaction (Hypothesis 2c), and higher job performance (Hypothesis 2d).

\section{Perceived Pressures}


The second dimension constitutes perceived pressures that act upon a person's preference to use or not use a specific work-life practice. It is widely known that constraints from the social context, both at work and at home, can induce pressures upon employees to act in another way than their preferred one (Poelmans, 2005). Also in the context of work-life practices, external pressures may act upon a person's personal preference for use or non-use of a specific practice. Although research on work-life practices has rarely explicitly included these external pressures, there are several indications in the literature of their existence. Both the work environment and the private life have been repeatedly identified as contexts from which external pressures can arise.

First, several studies have pointed to the existence of pressures from the work environment, especially pressures to not make use of work-life practices. For example, a family-unfriendly organizational culture, in particular the fear for negative career consequences, has been found to decrease practice use - suggesting that it pressures employees towards not making use of these practices - as well as to negatively affect employee outcomes above and beyond practice use (Anderson et al., 2002; Behson, 2005; Kossek et al., 2010; Ryan \& Kossek, 2008; Thompson et al., 1999). Also the supervisor or colleagues may induce perceived pressures to not make use of work-life practices, for example when they show little understanding for family issues (Thompson, Beauvais, \& Lyness, 1999) or, when one's use of these practices may complicate work organization (Ilgen, Hollenbeck, Johnson \& Jundt, 2005) or risks to trigger negative group mood because of reduced physical visibility at the work floor (Bartel \& Saavedra, 2000). The work environment could also induce pressure to make use of offered work-life practices, although this possibility has been mentioned less often in the literature. An indirect reference to this possibility has been made by Hoffman and Cowan (2008), who argued that organizations exert power over their employees by offering work-life practices for their employees. 
Therefore - by simply offering these practices - organizations may induce a pressure on their employees to make use of these opportunities. Organizations could also exert pressure on individuals to use work-life practices in other ways, for instance by reducing the office space, in that way inducing a pressure on their employees to work from home.

Second, several studies indicate that also a person's private life may induce pressures to either use or not use work-life practices. For instance, having children and having more family demands have been repeatedly linked with the use of work-life practices (Kossek et al., 2006; Shockley \& Allen, 2010). Having children and family demands is logically inducing a need for these practices, but if an employee has a preference to not use these practices, this need may be perceived as a pressure. In the latter case, making use of these practices could feel as beyond one's personal control, which has been associated with lower work attitudes and performance (Spector, 1986). This could explain why some studies have found family demands to decrease the benefits of work-life practice use (e.g., Hill et al., 1998), whereas others found the opposite, i.e., family demands increasing the benefits of practice use (Butts et al., 2015; Saltzstein et al. 2001; Ten Brummelhuis \& Van der Lippe, 2010). The private environment may also pressure employees to not use work-life practices. For instance, financial pressures might pressure employees to not make use of part-time work (Bielby \& Bielby, 1989; Zabalza, Pissarides \& Barton, 1980). Also, having children may sometimes induce a pressure on employees to not use telework since people with children may expect more interruptions while working at home which would decrease the expected productivitybenefits of this practice (Demerouti et al., 2014; Ten Brummelhuis \& Van der Lippe, 2010).

Experiencing such external pressures, either from the work environment or from one's private life, is not without consequence. According to motivational theories of work (Gagné \& Deci, 2005), experiencing pressures to conduct work in another way than the preferred one, may lead to more controlled forms of work motivation. As controlled forms of motivation 
have been found to be negatively linked with employee outcomes (Gagné \& Deci, 2005), pressures arising from the work or private life context might lead to negative outcomes. External pressures are also likely to reduce the sense of personal control over one's situation. As perceived control - or perceived autonomy - has repeatedly been found to predict positive employee outcomes (Spector, 1986), also in the sphere of work-life practices (Kossek, Lautsch \& Eaton, 2006; Thompson \& Prottas, 2006), a reduced sense of control is likely to be associated with more negative employee outcomes.

Therefore, and in line with suggestions of Poelmans (2005) and Demerouti and colleagues (2014), we include pressures for use and non-use that arise from the work environment (i.e., work pressures) and from one's private life (i.e., private pressures) above personal preferences to understand outcomes of work-life practices. In line with the reasoning above, we expect that employees who perceive more pressures, either from the work or the private environment, are likely to experience less perceived control over their situation and to show lower work attitudes and performance outcomes. Consequently, we formulate the following hypotheses for home-based telework and part-time work:

Hypothesis 3. Higher perceived work pressures for use or non-use of home-based telework which are not in line with ones preferences for use or non-use of home-based telework, will lead to higher work-life conflict (Hypothesis 3a), higher life-work conflict (Hypothesis 3b), lower job satisfaction (Hypothesis 3c), and lower job performance (Hypothesis 3d).

Hypothesis 4. Higher perceived private pressures for use or non-use of home-based telework which are not in line with ones preferences for use or non-use of home-based telework, will lead to higher work-life conflict (Hypothesis 4a), higher life-work conflict (Hypothesis 4b), lower job satisfaction (Hypothesis 4c), and lower job performance (Hypothesis 4d).

Hypothesis 5. Higher perceived work pressures for use or non-use of part-time work which are not in line with ones preferences for use or non-use of part-time work, will lead 
to higher work-life conflict (Hypothesis 5a), higher life-work conflict (Hypothesis 5b), lower job satisfaction (Hypothesis 5c), and lower job performance (Hypothesis $5 d$ ).

\section{Hypothesis 6. Higher perceived private pressures for use or non-use of part-time work} which are not in line with ones preferences for use or non-use of part-time work, will lead to higher work-life conflict (Hypothesis 6a), higher life-work conflict (Hypothesis 6b), lower job satisfaction (Hypothesis 6c), and lower job performance (Hypothesis 6d).

\section{Interaction Between Preferences and Perceived Pressures}

In addition to these main effects of preferences and perceived pressures, we hypothesize that perceived pressures can also moderate the positive effects of fit between people's preferences for either use or non-use and their actual use or non-use on conflict, work attitudes and performance outcomes. In particular, we expect that external pressures acting upon one's own preference for use or non-use might attenuate the positive effects of this fit. These suggestions are in line with job demands-resources models (Bakker \& Demerouti, 2007) which state that high demands can reduce positive effects of job resources on employee outcomes. High fit between people's preference for either use or non-use of a specific worklife practice and their actual use or non-use of that practice may function as a resource because fit, as we hypothesized above, is likely to be associated with intrinsic and autonomous motivation and may thus involve a motivating power which can empower and energize individuals. Perceived pressures may function as demands as they are likely to be associated with low perceived control (Kossek et al., 2006; Thompson \& Prottas, 2006) and more controlled forms of motivation (Gagné \& Deci, 2005) and may therefore require sustained psychological effort from the individual. When people experience more demands, like more perceived external pressures, they may need more of the energy induced by their resources, like fit, to handle these demands, and this could reduce the positive effects of these resources. Also scholars in the domain of boundary management styles have theorized that external pressures, in particular pressures arising from the organizational climate, may 
negatively affect the benefits of fit, in particular fit between preferences for a certain boundary management style and actual enactment of that style (Kossek \& Lautsch, 2012; Kreiner, 2006). We therefore posit the following hypotheses:

Hypothesis 7. The effect of a high fit between one's preferences for use or non-use of home-based telework and actual use or non-use of home-based telework will be moderated by perceived work pressures. Specifically, higher perceived work pressures will inhibit the beneficial effects of fit on work-life conflict (Hypothesis 7a), life-work conflict (Hypothesis 7b), job satisfaction (Hypothesis 7c), and job performance (Hypothesis 7d).

Hypothesis 8. The effect of a high fit between one's preferences for use or non-use of home-based telework and actual use or non-use of home-based telework will be moderated by perceived private pressures. Specifically, higher perceived private pressures will inhibit the beneficial effects of fit on job satisfaction (Hypothesis 8a), work-life conflict (Hypothesis 8b), life-work conflict (Hypothesis 8c), and job performance (Hypothesis $8 d$ ).

Hypothesis 9. The effect of a high fit between one's preferences for use or non-use of part-time work and actual use or non-use of part-time work will be moderated by perceived work pressures. Specifically, higher perceived work pressures will inhibit the beneficial effects of fit on work-life conflict (Hypothesis 9a), life-work conflict (Hypothesis 9b), job satisfaction (Hypothesis 9c), and job performance (Hypothesis 9d).

Hypothesis 10. The effect of a high fit between one's preferences for use or non-use of part-time work and actual use or non-use of part-time work will be moderated by perceived private pressures. Specifically, higher perceived private pressures will inhibit the beneficial effects of fit on work-life conflict (Hypothesis 10a), life-work conflict (Hypothesis 10b), job satisfaction (Hypothesis 10c), and job performance (Hypothesis $10 d)$.

A visual presentation of the model that is tested in the current study, with references to all hypotheses, is shown in Figure 1.

Insert Figure 1 about here 


\section{METHOD}

\section{Sample and Procedures}

Data were collected at a middle-large Belgian university through an on-line survey during the summer of 2015. All staff members, including academic as well as administrative and technical staff, were approached via e-mail to fill in the survey and one e-mail reminder was sent. Both an English and a Dutch version was provided. A total of 382 staff members filled out the questionnaire. The majority of the sample was female (59.4\%). Respondents were between 20 and 70 years old $(M=39.64, S D=11.38)$ and had between 0 and 6 children $(M=$ $1.14, S D=1.14)$ (Table 1). Furthermore, $58.5 \%$ of the respondents made use of home-based telework and $23.8 \%$ made use of part-time work.

\section{Measures}

Fit between preferences and use or non-use of practices. We developed a four-item scale to measure the fit between people's preference for use or non-use and their actual use or non-use of home-based telework $(\alpha=.93)$ and part-time work $(\alpha=.89)$. In particular, respondents rated four items on the extent to which their use or non-use of telework (respectively, part-time work) was conform with what they would prefer on a five-point Likert scale (1: Totally disagree -5 : Totally agree). Since we aimed to measure the fit between employees' preferences and their actual use or non-use, the statements differed according to their use or non-use of the work-life practices. For employees who made use of home-based teleworking (part-time work), the statements used were: (1) "I make use of home-based teleworking (part-time work) because I truly want this"; (2) "I would preferably not make use of home-based teleworking (part-time work)" (reverse scored); (3) "It is entirely my own decision to make use of home-based teleworking (part-time work)"; (4) "If it was entirely up to me, I would not make use of home-based teleworking (part-time work)" (reverse scored). For employees who did not make use of home-based teleworking (part-time 
work), the statements were: (1) "I do not make use of home-based teleworking (part-time work) because I truly want it like this"; (2) "I would preferably make use of home-based teleworking (part-time work)" (reverse scored); (3) "It is entirely my own decision to not make use of home-based teleworking (part-time work)"; (4) "If it was entirely up to me, I would make use of home-based teleworking (part-time work)" (reverse scored).

Perceived pressures to use or not use practices. To measure perceived work pressures and perceived private pressures to make use or to not make use of work-life practices, we used single-item measures based on the perceived pressure-measures developed by Greenhaus and Powell (2003). Greenhaus and Powell (2003) investigated the effects of work and family pressures upon decisions to participate in either a work or a family activity. They manipulated experimental vignettes and used the following single-item question to check manipulations: "In the incident, how much pressure is your manager (spouse) placing on you to participate in the overtime work session on the project (attend the surprise birthday party for your parent)?”. Similarly, we asked our respondents to rate how much pressure they perceived from their work environment and from their private life to make use or to not make use of the specific work-life practices. For respondents who preferred to use home-based telework (part-time work), perceived work pressures and perceived private pressures were measured through agreement with the following statements: (1) "I experience pressure from my work or employer to not make use of home-based teleworking (part-time work)"; and (2) "I experience pressure from my private life to not make use of home-based teleworking (parttime work)". For respondents who preferred to not use home-based telework (part-time work), perceived work pressures and perceived private pressures were measured through agreement with the following statements: (1) "I experience pressure from my work or employer to make use of home-based teleworking (part-time work)"; (2) "I experience pressure from my private life to make use of home-based teleworking (part-time work)". The response scale ranged 
from 0 (Totally disagree) to 10 (Totally agree). A high score implies that a respondent experienced high pressures acting upon his or her personal preference.

Work-life conflict. Work-life conflict was measured using the six-item scale developed by Carlson, Kacmar and Williams (2000) $(\alpha=.90)$. Sample items were "My job keeps me more from doing activities in my private life than I would like to" and "My job makes it difficult for me to participate enough in responsibilities and activities at home". The response scale ranged from 1 (Totally disagree) to 5 (Totally agree).

Life-work conflict. We also used the six-item scale developed by Carlson, Kacmar and Williams (2000) to measure life-work conflict $(\alpha=.84)$. Sample items were "The time I spend on my private life hinders me to do my job properly" and "The time I spend on my private life often makes that I cannot spend time on job activities which might be fruitful for my further career". The response scale ranged from 1 (Totally disagree) to 5 (Totally agree).

Job satisfaction. To measure job satisfaction, we used the three-item job satisfaction scale developed by Cammann, Fichman, Jenkins and Klesh (1979) $(\alpha=.85)$. Respondents were asked to rate the following statements: (1) “All in all I am satisfied with my job”; (2) "Generally I don't like my job" (reverse scored); (3) "Generally I like to work here". The response scale ranged from 1 (Totally disagree) to 5 (Totally agree).

Job performance. To measure job performance, we used the three-item subscale of individual task proficiency of the work performance scale developed by Griffin, Neal and Parker (2007) $(\alpha=.75)$. The individual task efficiency scale gauges at performance behaviors that are not embedded in a social context. Respondents indicated to what extent they agreed with the following statements: (1) "I perform the core tasks of my job well”; (2) "I do my job the way it was intended"; (3): "I accomplish my tasks as it should". The response scale ranged from 1 (Totally disagree) to 5 (Totally agree). 
Controls. We included control variables that have been hypothesized to influence worklife conflict, life-work conflict, job satisfaction, and job performance. The following controls were included: gender $(0=$ man; $1=$ woman $)$, age (in years), and number of children. In addition, we included use of home-based telework (1: yes; 0: no) as a control in the regressions on home-based telework and use of part-time work (1: yes; 0: no) in the regressions on part-time work.

\section{Analyses}

Moderated hierarchical regression analysis were used to test the hypotheses. We performed four hierarchical regressions for home-based telework and four for part-time work, one for each dependent variable (i.e., work-life conflict, life-work conflict, job satisfaction and job performance). In a first step, control variables (i.e., age, gender, number of children, use of the specific work-life practice) were entered (Model 1). The inclusion of use of the specific work-life practice is a central point in our study, as we argue that it is not the use of practices, but rather the cognitive conditions accompanying the use or non-use of a practice that are important to understand work outcomes. In the second step, our key explanatory variables (i.e., fit between preferences and actual use or non-use, perceived work pressures, and perceived private pressures) were added. In a final step, interactions between fit and both pressure variables were added (Model 3). Multicollinearity was checked for all predictors by a tolerance analysis (i.e., the variance proportion in the dependent variable that is not explained by the predictor). A predictor's tolerance value lower than .10 indicate a risk of multicollinearity (Tabachnick \& Fidell, 2001) and in that case, that variable should not be included, as it can bias regression outcomes. For home-based telework, none of the predictors' tolerance was below .10. For part-time work, tolerance of the interaction between fit and private pressures was below .10 (Tolerance $=.08)$. We therefore left this variable out of further analysis. 


\section{RESULTS}

Basic descriptive statistics of the sample, reliability coefficients, and correlations of control variables, independent variables and dependent variables are shown in Table 1.

Insert Table 1 about here

Table 2 shows the regression outcomes for home-based telework and Table 3 shows those for part-time work. As we explained above, each regression was done in 3 steps. In what follows, we discuss the step 2-regression results for fit and pressures if the inclusion of the interaction term with a specific pressure in step 3 was not significant or if step 3 as a whole was found to be non-significant. We discuss the regression results from step 3 if this step significantly improved the explained variance of the model and if the inclusion of that interaction term was significant. In the latter case, effects are plotted in a graph to facilitate interpretation. An overview of support or non-support for all hypotheses is shown in Table 4.

Insert Table 2 about here

Insert Table 3 about here

\section{Main Effects of Fit}

Home-based telework. Hypothesis 1 expected that the fit between preferences for either use or non-use of telework and actual use or non-use would result in negative effects on worklife conflict $(H 1 a)$ and life-work conflict $(H 1 b)$, and in positive effects on job satisfaction $(H 1 c)$ and job performance $(H 1 d)$. As shown in Table 2, fit between one's preference for the use or non-use of home-based telework and one's actual use or non-use was found to have a negative effect on work-life conflict (Step 3: $\beta=-0.46, p<.01$ ), a negative effect on lifework conflict (Step 2: $\beta=-0.16, p<.05$ ), and a positive effect on job satisfaction (Step 2: $\beta$ 
$=0.18, p<.05)$. This is in line with hypotheses Hla, H1b and Hlc. However, HId was not supported as for job performance, adding predictor variables above control variables did not increase the explained variance of the model (Step 2: $\Delta R^{2}=.02, p=.11$ ).

Part-time work. Hypothesis 2 expected that the fit between preferences for either use or non-use of part-time work and actual use or non-use would be associated with less work-life conflict $(H 2 a)$, less life-work conflict $(H 2 b)$, more job satisfaction $(H 2 c)$ and more job performance $(H 2 d)$. As shown in Table 3, fit between people's preferences for use or non-use of part-time work and their actual situation was found to be negatively related with work-life conflict (Step 2: $\beta=-0.13, p<.05$ ). This supported $H 2 a$. Yet, we found no effect on lifework conflict (Step 3: $\beta=-0.10, p=.17$ ) and thus no support for $H 2 b$. We found a marginally significant positive effect of fit on job satisfaction (Step 2: $\beta=0.12, p<.10$ ), which partially confirmed $H 2 c . H 2 d$ was not confirmed as for job performance, adding predictor variables above control variables did not increase explained variance of the model (Step 2: $\left.\Delta R^{2}=.01, p=.28\right)$.

\section{Main Effects of Perceived Pressures}

Home-based telework. Hypothesis 3 and 4 expected that perceived work pressures (H3) and perceived private pressures (H4) acting upon one's preferences for using telework would be associated with more work-life conflict $(H 3 a, H 4 a)$, more life-work conflict $(H 3 b, H 4 b)$, lower job satisfaction $(H 3 c, H 4 c)$, and lower job performance $(H 3 d, H 4 d)$. For work pressures, we did not find an effect on work-life conflict (Step 3: $\beta=-0.25, p=.11$ ) nor on life-work conflict (Step 2: $\beta=0.07, p=.28$ ). We can therefore not confirm $H 3 a$ nor $H 3 b$. We did find a negative effect of work pressures on job satisfaction $(\beta=-0.15, p<.05)$ as expected in $H 3 c$. We found no support for $H 3 d$, however, as for job performance, adding predictor variables above control variables did not increase variance (Step 2: $\Delta R^{2}=.02, p=$ .11). For private pressures, we found a significantly negative - and thus not the expected 
positive - effect on work-life conflict (Step 2: $\beta=-0.11, p<.05$ ). Respondents who experienced more private pressures thus reported on average lower rather than higher worklife conflict. Since the direction of this effect was contrary to the expected direction in $H 4 a$, we cannot support this hypothesis. We did find the expected positive effect of private pressures on life-work conflict (Step 2: $\beta=0.19, p<.01$ ), which confirmed $H 4 b$. We found no effect of private pressures on job satisfaction $(\beta=0.03, p=.59)$ and therefore cannot confirm $H 4 c$. Finally, we found no support for $H 4 d$ as for job performance, adding predictor variables above control variables did not increase variance (Step 2: $\Delta R^{2}=.02, p=.11$ ).

Part-time work. Hypothesis 5 and 6 expected that perceived work pressures (H5) and perceived private pressures (H6) acting upon one's preferences for using part-time work would be associated with more work-life conflict $(H 5 a, H 6 a)$, more life-work conflict $(H 5 b$, $H 6 b)$, lower job satisfaction $(H 5 c, H 6 c)$, and lower job performance $(H 5 d, H 6 d)$. As shown in Table 3, we found a positive effect of work pressures on work-life conflict (Step 3: $\beta=0.13, p$ $<.01$ ), which confirmed $H 5 a$. We found no effect of work pressures on life-work conflict (Step 2: $\beta=-0.20, p=.18$ ), nor on job satisfaction (Step 2: $\beta=-0.10, p=.12$ ). We can thus not confirm $H 5 b$ or $H 5 c$. $H 5 d$ was also not supported as for job performance, adding predictor variables above control variables did not increase explained variance (Step 2: $\Delta R^{2}=.01, p=$ .28). Concerning private pressures, we found support for $H 6 a, H 6 b$ and $H 6 c$, as private pressures were related with more work-life conflict (Step 2: $\beta=0.11, p<.05$ ), with more lifework conflict (Step 3: $\beta=0.22, p<.01$ ) and less job satisfaction (Step 2: $\beta=-0.13, p<.05$ ). $H 6 d$ was not supported as for job performance, adding predictor variables above control variables did not increase explained variance (Step 2: $\left.\Delta R^{2}=.01, p=.28\right)$.

\section{Interaction Effects of Fit and Perceived Pressures}

Home-based telework. It was hypothesized that perceived work pressures (H7) and perceived private pressures (H8) affecting use of telework would attenuate effects of fit on 
work-life conflict $(H 7 a, H 8 a)$, life-work conflict $(H 7 b, H 8 b)$, job satisfaction $(H 7 c, H 8 c)$ and job performance $(H 7 d, H 8 d)$. As shown in Table 2, we found one significant interaction effect, i.e., between fit and work pressures in the regression on work-life conflict $(\beta=0.44, p$ $<.01)$. This effect is plotted in Figure 2. We see that in case of low work pressures, higher fit between people's preference for use or non-use of telework and their actual use or non-use of the practice was associated with less work-life conflict. This relationship was attenuated - and even reversed - in case of high work pressures. This is in line with $H 7 a$.

Part-time work. It was hypothesized that perceived work pressures (H9) and perceived private pressures (H10) affecting use of part-time work would attenuate the effects of fit on work-life conflict $(H 9 a, H 1 O a)$, life-work conflict $(H 9 b, H 1 O b)$, job satisfaction $(H 9 c, H 1 O c)$ and job performance $(H 9 d, H 1 O d)$. As multicollinearity was not met for the interaction between fit and private pressures (Tolerance $=.08$ ), only hypotheses concerning the interaction with work pressures $(H 9 a, H 9 b, H 9 c$, and $H 9 d)$ were analyzed. As shown in Table 3 , we found one significant interaction effect, i.e., in the regression for life-work conflict $(\beta=$ $0.26, p<.05)$. This effect is plotted in Figure 2. The figure shows that in case of low work pressures, fit is associated with lower life-work conflict than misfit, whereas in case of high work pressures, fit does not seem to affect life-work conflict. Higher work-pressures thus seem to diminish the beneficial effect of fit, as we expected. We can thus confirm $H 9 b$.

Insert Figure 2 about here

\section{Effects of Use}

Finally, we have a look at the impact of the use of telework and the use of part-time work. In our theorizing, we posited that it is not whether employees use a specific work-life practice, but rather the cognitive conditions accompanying use or non-use of these practices that explain employees' work-life and life-work conflict, job satisfaction and job 
performance. Our analyses allow us to evaluate this assumption by comparing the explained variance of Model 1 (in which the mere effect of practice use is examined, as done in traditional studies investigating the effect of practice use) with the explained variance of Models 2 and 3.

For home-based telework (see Table 2), we see a significant impact of use of telework on work-life conflict $(\beta=0.21, p<.01)$, life-work conflict $(\beta=0.12, p<.05)$ and job performance $(\beta=-0.14, p<.05)$ in Model 1 ; yet, this impact is contrary to the one which is typically expected. Indeed, employees who make use of home-based telework were found to report on average more work-life conflict, more life-work conflict and lower job performance. In addition, the inclusion of the cognitive conditions accompanying use or non-use of homebased telework, i.e., fit and perceived pressures, in step 2 was found to more than double the explained variance of work-life conflict, life-work conflict and job satisfaction compared to step 1. This supports our expectation that the cognitive cognitions fit and perceived pressures are more important for accounting for differences in these outcome variables. For job performance, however, this was not the case as for this variable, the inclusion of fit and perceived pressures did not significantly improve the model fit.

For part-time work (Table 3), we see a marginally significant impact of the use of parttime work on work-life conflict in step $1(\beta=-0.11, p<.10)$. No impact of use was found on the other outcome variables in step 1 . In addition, the inclusion of the cognitive conditions fit and perceived pressures in step 2 was found to more than double the explained variance of work-life conflict, life-work conflict and job satisfaction compared to step 1. So, also for parttime work, the cognitive cognitions fit and perceived pressures seem to be more important for accounting for differences in outcome variables than the mere use of this practice. For job performance, however, this was not the case since for this variable, the inclusion of fit and perceived pressures did not significantly improve the model fit. 


\section{DISCUSSION}

In this study, we hypothesized that it is not the mere use of work-life practices, but rather cognitive conditions accompanying use or non-use of these practices that account for employee outcomes (i.e., work-life conflict, life-work conflict, job satisfaction, and job performance). Specifically, we hypothesized that fit between people's preferences for use or non-use of a specific practice and their actual use or non-use would be associated with positive employee outcomes (i.e., lower work-life conflict, lower life-work conflict, more job satisfaction and better job performance), whereas perceived pressures from the work context or from one's private life would be associated with negative employee outcomes (i.e., higher work-life conflict, higher life-work conflict, lower job satisfaction and lower job

performance). In addition, we expected that perceived pressures would attenuate the hypothesized positive effects of fit. We studied these effects for one flexibility practice, i.e., home-based telework, and for one work-time reduction practice, i.e., part-time work.

Overall, we found large support for the main proposition of this paper, i.e., that the cognitive conditions accompanying use or non-use of a specific work-life practice are more important than the mere use of that practice to understand employee outcomes. In particular, the two cognitive conditions we included in this study, i.e., (1) fit between people's preference for using home-based telework and part-time work and their actual use or non-use of each respective practice, and (2) the external pressures they perceived from either the work context or from their private life acting upon that preference, were found to explain at least double - and up to seven times - the variance in work-life conflict, life-work conflict and job satisfaction than the mere use of these practices. Only job performance was not explained in a significant way by fit and perceived pressures. A possible explanation for this result might be that fit and perceived pressures, being cognitive variables, are more directly related to cognitive outcomes, such as conflict and work attitudes, and not to behavioral ones, such as 
performance. It could therefore be interesting for future research to explore also indirect effects of fit and pressures on job performance through, for instance, job satisfaction (Judge, Thoresen, Bono \& Patton, 2001). Another explanation could lie in the rather low variance in job performance in our sample, which may have made it harder to find significant effects for this variable. Future research should therefore explore this relationship in samples with more variation on this variable.

Our results strongly support the importance of the first condition, i.e., the fit between people's preference to make use of home-based telework and part-time work and their actual use of these specific practices, for understanding work-life conflict, life-work conflict and job satisfaction. In particular, fit was found to impact work-life conflict, life-work conflict and job satisfaction in all but one regression. The importance of fit between people's preference for using a specific work-life practice and their actual use is both in line with motivational theories of work (Gagné \& Deci, 2005), which posit that the extent to which intrinsic or autonomous motivation for work characteristic will be attained depends on factors which differ within employees, and with fit theories (e.g. Boon et al., 2011; Kristof-Brown et al., 2005), which state that one should take into account individual differences like preferences for certain work characteristics when trying to understand the impact of these work characteristics. We found no significant effect of fit, however, in the regression examining the impact of fit between people's preference for part-time work and their actual use of part-time work on people's life-work conflict. The interaction analysis did reveal a beneficial effect of fit on life-work conflict, but only when employees experienced low pressures from their work environment. It thus seems that fit between people's preference for part-time work and their actual use of part-time work can reduce people's life-work conflict, but only in the case of low work pressures. 
Also the second cognitive condition included in this study, i.e., perceived pressures from both the working environment and from one's private life, was found to affect work-life conflict, life-work conflict and job satisfaction, though not all hypotheses about this condition were confirmed. As hypothesized, we found work pressures acting upon one's preference for home-based telework to be associated with less job satisfaction, and work pressures acting upon one's preference for part-time work to be linked with more work-life conflict. In addition, private pressures acting upon one's preference for home-based telework were found to be associated with more life-work conflict and private pressures acting upon one's preference for part-time work were linked with more work-life conflict, more life-work conflict and less job satisfaction. Perceiving external pressures may induce more controlled forms of motivation and reduce people's perceived control over their situation, which could explain these link with negative employee outcomes (Thompson \& Prottas, 2006).

Interestingly, perceived pressures acting upon one's preferences for part-time work seemed to be more influential (i.e., exerted a significant impact in more regressions) than perceived pressures acting on one's preference for home-based telework. This result underscores the importance of differentiating between specific work-life practices. Relatedly, pressures from one's private life seemed to be more important (i.e., exert a significant effect in more regressions) than perceived pressures from the work context. The importance of distinguishing between sources of pressures is in line with findings from other research domains, like research on embeddedness (Lee, Mitchell, Sablynski, Burton \& Holtom, 2004) and turnover (Hom, Mitchell, Lee \& Griffeth, 2012).

Overall, it seems important for future research to further examine why these differences between different work-life practices and between the different sources of external pressures occur and to include these explanations in further theorizing on this issue. 
The other hypotheses on perceived external pressures from the work environment and from one's private life were not supported, indicating that perceived pressures are not equally relevant for each relationship between a specific work-life practices and a specific outcome. One finding is particularly noteworthy since it turned out to go in the opposite direction than we expected initially, i.e., we found private pressures acting upon one's preference for homebased telework to be associated with less rather than more work-life conflict. Perhaps, employees who experience little work-life conflict experience so little conflict because their partner takes up most of the home responsibilities. This partner may in turn pressure the employee to work more from home to be able to take over some of these responsibilities, which could explain why low work-life conflict is associated with high private pressures. Further research on the nature of these private pressures, preferably studied in a couple setting, could help to better understand this issue.

Above the main effects of fit and perceived pressures, we also investigated interaction effects between these two predictors. Note, however, that for part-time work, we were only able to analyze interaction effects between fit and work pressures due to multicollinearity problems of the interaction term between fit and private pressures. We found two significant interaction effects, i.e., (1) an interaction of fit between one's preference for telework and one's actual use of telework on the one hand and pressures from the working environment on the other hand on people's work-life conflict and (2) an interaction of fit between people's preference for part-time work and their actual use of part-time work on the one hand and pressures from the working environment on the other hand on life-work conflict. In both regressions, we found work pressures to attenuate the positive effect of fit on conflict. This is in line with our expectations that demands, like perceived pressures, consume energy induced by resources, such as fit, and therefore reduce the positive effects of these resources. These results show how effects of fit between preferences and use, and perceived pressures do not 
act completely independent from each other, which has also been found in other research domains (Kreiner, 2006).

\section{Implications for Research and Practice}

Our results first of all indicate the need for scholars to rethink how we evaluate the effectiveness of work-life practices. To date, studies on work-life practices have indicated that work-life practices are not always used when available (Allen et al., 2013; McDonald, Brown \& Bradley, 2005), and if they are used by employees, use is not always associated with the intended positive effects on employee outcomes (e.g., Butts et al.., 2013). We argue that the non-use of available practices does not have to indicate a failed implementation policy, neither does use of these practices imply a successful implementation. Rather, our results point towards an employee-centered approach that focusses on cognitions of fit between preferences and actual use and of perceived pressures to evaluate the success of a work-life policy implementation. This suggestion follows up on recommendations from other scholars to look at effectiveness of specific work-life practices at the employee level rather than to look at cyphers of availability, use, and non-use of HR-practices at the organizational level (Guest \& Boss-Nehles, 2013).

To take into account the distinction between preferences and pressures is to acknowledge the difference between employees' wants and needs respectively. Some studies on work-life issues did already mention preference concepts, yet they did not specifically distinguish preferences from pressures. For instance, Thornthwaite (2004) found preferences for worklife practices to differ between employees, yet preferences were framed in terms of different demands, for instance family demands or demands of the specific job. In line with suggestions of previous scholars (Kossek \& Ruderman, 2012), we argue that these demands may be internalized and function as preferences (i.e., wants) or otherwise may function as pressures (i.e., needs). This may explain current inconsistencies in the moderating effects of family 
demands on the relation between use of work-life practices and employee outcomes (e.g., Hill et al., 1998, Butts et al., 2015; Saltzstein et al. 2001; Ten Brummelhuis, \& Van der Lippe, 2010). Therefore, we operationalize needs not in terms of objective measures such as quantitative work time demands or number of children, but rather in terms of pressures as perceived by employees themselves. To focus on these cognitive aspects is in line with motivation theories (Deci \& Ryan, 1985; Gagné \& Deci, 2005) and decision process theories (March, 1994; Poelmans, 2005) which have suggested to include the work environment and the private life when studying work motivations and decisions and outcomes of these decisions. Influences from both the work environment and the private life may induce perceived pressures in employees.

Our findings are also relevant for practitioners. Building on our results, organizations may profit from work-life policies wherein employees are enabled to make use of work-life practices if they want to (i.e., organizations may make work-life policies available), without imposing perceived negative consequences of use or non-use of offered practices. Enabling employees more control over use or non-use of practices without pressuring them seems to be key in successful implementation. Yet, our results also showed that pressures from employees' private life are predictive for employee outcomes. Therefore, effective organizational implementation of work-life practices may be insufficient to guarantee worklife practices triggering positive outcomes. Career counseling could play a role here to help employees to cope with pressures from their private life. For instance, research has shown that employees can benefit from certain psychological techniques to cope with opponent responsibilities from different life roles (Versey, 2005). In addition, career counselors should not overlook the employee's household situation and/or open up the dialogue between employees' and their partners to optimize the conditions for positive work-life outcomes for employees (Hammer et al., 2005; Ten Brummelhuis \& Van der Lippe, 2010). 


\section{Limitations and Future Research}

Our study has a number of limitations. First, some methodological considerations can be made. We used single-item measures to measure perceived pressures. Future research may want to develop and validate multiple item scales to improve the assessments of perceived pressures. We also used cross-sectional data and therefore cannot rule out correlational instead of causal effects. Future research might benefit to include measurements of preferences and perceived pressures at time points both before decisions affecting use and non-use of practices, and after these decisions. In this way, decisions in themselves might be studied in more detail, which may reveal possible effects of cognitive dissonance and internalization (i.e., becoming satisfied with circumstances as they are and internalize these circumstances as your own preference).

The previous consideration brings us to more theoretical limitations in this study. First, the distinction between preferences and pressures might not be straightforward. Specifically, according to March' decision process theory (1994), indicating preferences for certain circumstances (like use of work-life practices) might be contaminated by the actual situation wherein one finds himself/herself. Consequently, preferences for work conditions cannot always be seen distinct from the possibilities to which one is able to act in accordance with these preferences. In addition, in their review on choice regarding work-life balance issues, Gregory and Milner (2009) state "preferences [are] shaped not only by individual values and predispositions but also by current reality (...) [and] thus, preferences take account of perceived constraints" (p. 3). Especially demands from the private environment might, for some, be internalized as one's own preferences, as already suggested by other scholars (Kossek \& Ruderman, 2012). Lastly, preferences may not be stable concepts (Bazerman, Tenbrunsel \& Wade-Benzoni, 1998; March, 1994). Longitudinal studies may be more appropriate to address these limitations. 


\section{Conclusion}

In this study, we showed the relevance of including cognitive conditions accompanying use or non-use of work-life practices for understanding the effectiveness of these practices. We found evidence that (1) fit between preferences and actual use of home-based telework and part-time work and (2) perceived pressures from the work environment and the private environment on people's preferences to use these practices explained variance in work-life conflict, life-work conflict and job satisfaction above and beyond the mere use of these worklife practices. We therefore encourage scholars and practitioners to include motivational aspects rather than measures of mere use or non-use of work-life practices when studying the effectiveness of work-life policies.

\section{REFERENCES}

Allen, T., Johnson, R., Kiburz, K., \& Shockley, K. 2013. Work-family conflict and flexible work arrangements: Deconstructing flexibility. Personnel Psychology, 66(2): 345-376.

Anderson, S., Coffey, B., \& Byerly, R. 2002. Formal organizational initiatives and informal workplace practices: Links to work-family conflict and job-related outcomes. Journal of Management, 28(6): 787-810.

Bakker, A., \& Demerouti, E. (2007). The job demands-resources model: State of the art. Journal of Managerial Psychology, 22(3): 309-328.

Bartel, C. \& Saavedra, R. 2000. The collective construction of work group moods. Administrative Science Quarterly, 45: 197-231.

Bazerman, M., Tenbrunsel, A., \& Wade-Benzoni, K. 1998. Negotiating with yourself and losing: Making decisions with competing internal preferences. Academy of Management Review, 23(2): 225-241.

Beauregard, T., \& Henry, L. 2009. Making the link between work-life balance practices and organizational performance. Human Resource Management Review, 19(1): 9-22.

Behson, S. 2005. The relative contribution of formal and informal organizational work-family support. Journal of Vocational Behavior, 66(3): 487-500.

Bielby, W., \& Bielby, D. 1989. Family ties: Balancing commitments to work and family in dual earner households. American Sociological Review: 776-789.

Boon, C., Den Hartog, D., Boselie, P., \& Paauwe, J. 2011. The relationship between perceptions of HR practices and employee outcomes: Examining the role of personorganisation and person-job fit. The International Journal of Human Resource Management, 22(01): 138-162.

Butts, M., Casper, W., \& Yang, T. 2013. How important are work-family support policies? A meta-analytic investigation of their effects on employee outcomes. Journal of Applied Psychology, 98(1): 1-25. 
Byron, K. 2005. A meta-analytic review of work-family conflict and its antecedents. Journal of Vocational Behavior, 67(2): 169-198.

Cammann, C., Fichman, M., Jenkins, D., \& Klesh, J. 1979. The Michigan organizational assessment questionnaire. Unpublished manuscript: University of Michigan, Ann Arbor.

Carlson, D., Kacmar, K., \& Williams, L. 2000. Construction and initial validation of a multidimensional measure of work-family conflict. Journal of Vocational Behavior, 56(2): 249-276.

Casper, W., \& Harris, C. 2008. Work-life benefits and organizational attachment: Self-interest utility and signaling theory models. Journal of Vocational Behavior, 72(1): 95-109.

Deci, E., \& Vansteenkiste, M. 2004. Self-determination theory and basic need satisfaction: Understanding human development in positive psychology. Ricerche di Psicologia, 27(1): 23-40.

Deci, E., \& Ryan, R. 1985. Intrinsic motivation and self-determination in human behavior. New York: Plenum.

Demerouti, E., Bakker, A. B., Nachreiner, F., \& Schaufeli, W. B. 2001. The job demandsresources model of burnout. Journal of Applied psychology, 86(3): 499-512.

Demerouti, E., Derks, D., ten Brummelhuis, L., \& Bakker, A. 2014. New ways of working: Impact on working conditions, work-family balance, and well-being. In C. Korunka \& P. Hoonakker (Eds.), The impact of ICT on quality of working life: 123-141. Netherlands: Springer.

Gagné, M., \& Deci, E. 2005. Self-determination theory and work motivation. Journal of Organizational Behavior, 26(4): 331-362.

Gajendran, R., \& Harrison, D. 2007. The good, the bad, and the unknown about telecommuting: A meta-analysis of psychological mediators and individual consequences. Journal of Applied Psychology, 92(6): 1524-1541.

Glass, J., \& Finley, A. 2002. Coverage and effectiveness of family-responsive workplace policies. Human Resource Management Review, 12: 313-337.

Greenhaus, J., \& Powell, G. 2003. When work and family collide: Deciding between competing role demands. Organizational Behavior and Human Decision Processes, 90(2): 291-303.

Greenhaus, J. \& Powell, G. 2012. The family-relatedness of work decisions: A framework and agenda for theory and research. Journal of Vocational Behavior, 80: 246-255.

Gregory, A., \& Milner, S. 2009. Work-life balance: A matter of choice? Gender, Work \& Organization, 16(1): 1-13.

Guest, D., E. \& Bos-Nehles, A. 2013. HRM and performance: The role of effective implementation. In J. Paauwe, D., Guest, P. \& P. Wright (Eds.), HRM and performance: Achievements and challenges: 81-96. Cornwall: TJ International Ltd.

Griffin, M., Neal,, \& Parker, S. 2007. A new model of work role performance: Positive behavior in uncertain and interdependent contexts. Academy of Management Journal, 50(2), 3:27-347.

Hammer, L., Allen, E., \& Grigsby, T. 1997. Work-family conflict in dual-earner couples: Within-individual and crossover effects of work and family. Journal of Vocational Behavior, 50(2): 185-203. 
Hammer, L., Colton, C., Caubet, S., \& Brockwood, K. 2002. The unbalanced life: Work and family conflict. In J. C. Thomas \& M. Hersen (Eds.), Handbook of mental health in the workplace: $83-101$. Newbury Park, CA: Sage.

Hammer, L., Neal, M., Newsom, J., Brockwood, K., \& Colton, C. 2005. A longitudinal study of the effects of dual-earner couples' utilization of family-friendly workplace supports on work and family outcomes. Journal of Applied Psychology, 90(4): 799-810.

Hartman, R., Stoner, C., \& Arora, R. 1991. An investigation of selected variables affecting telecommuting productivity and satisfaction. Journal of Business and Psychology, 6(2): 207-225.

Henz, U., \& Mills, C. 2014. Work-life conflict in Britain: Job demands and resources. European Sociological Review, jcu076.

Hill, E., Miller, B., Weiner, S., \& Colihan, J. 1998. Influences of the virtual office on aspects of work and work/life balance. Personnel Psychology, 51: 667-683.

Hill, E., Ferris, M., \& Martinson, V. 2003. Does it matter where you work? A comparison of how three work venues influence aspects of work and personal/family life. Journal of Vocational Behavior, 62: 220-241.

Hoffman, M., \& Cowan, R. 2008. The meaning of work/life: A corporate ideology of work/life balance. Communication Quarterly, 56: 227-246.

Hom, P., Mitchell, T., Lee, T., \& Griffeth, R. 2012. Reviewing employee turnover: Focusing on proximal withdrawal states and an expanded criterion. Psychological Bulletin, 138(5): 831-858.

Huselid, M. 1995. The impact of human resource management practices on turnover, productivity, and corporate financial performance. Academy of Management Journal, 38(3): 635-672.

Ilgen, D., Hollenbeck, J., Johnson, M., \& Jundt, D. 2005. Teams in organizations: From inputprocess-output models to IMOI models. Annual Review of Psychology, 56: 517-543.

Judge, T., Thoresen, C., Bono, J. \& Patton, G. 2001. The job satisfaction-job performance relationship: a qualitative and quantitative review. Psychological Bulletin, 127(3): 367407.

Kalliath, T., \& Brough, P. 2008. Work-life balance: A review of the meaning of the balance construct. Journal of Management \& Organization, 14(3): 323-327.

Kelly, E., Kossek, E., Hammer, L., Durham, M., Bray, J., Chermack, K., Murphy L. \& Kaskubar, D. 2008. Getting there from here: Research on the effects of work-family initiatives on work-family conflict and business outcomes. The Academy of Management Annals, 2(1): 305-349.

Kossek, E., \& Lautsch, B. 2012. Work-family boundary management styles in organizations A cross-level model. Organizational Psychology Review, 2(2): 152-171.

Kossek, E., Lautsch, B., \& Eaton, S. 2006. Telecommuting, control, and boundary management: Correlates of policy use and practice, job control, and work-family effectiveness. Journal of Vocational Behavior, 68(2): 347-367.

Kossek, E., Lewis, S., \& Hammer, L. 2010. Work-life initiatives and organizational change: Overcoming mixed messages to move from the margin to the mainstream. Human Relations, 63(1): 3-19.

Kossek, E., \& Ozeki, C. 1999. Bridging the work-family policy and productivity gap: A literature review. Community, Work and Family, 2(1): 7-32. 
Kossek, E., \& Ruderman, M. 2012. Work-family flexibility and the employment relationship. In L. Shore, J. Coyle-Shapiro \& L. Tetrick (Eds.), Understanding the employeeorganization relationship: Advances in theory and practice: $223-253$. New York: Taylor and Francis.

Kossek, E., Ruderman, M., Braddy, P., \& Hannum, K. 2012. Work-nonwork boundary management profiles: A person-centered approach. Journal of Vocational Behavior, 81: $112-128$.

Kreiner, G. 2006. Consequences of work-home segmentation or integration: A personenvironment fit perspective. Journal of Organizational Behavior, 27(4): 485-507.

Kristof-Brown, A., \& Jansen, K. 2007. Issues of person-organization fit. In C. Ostroff \& T. Judge, Perspectives on organizational fit: 123-153. Psychology Press.

Kristof-Brown, A., Zimmerman, R., \& Johnson, E. 2005. Consequences of individuals' fit at work: A meta-analysis of person-job, person-organization, person-group, and personsupervisor fit. Personnel Psychology, 58(2): 281-342.

Lee, T., Mitchell, T., Sablynski, C., Burton, J., \& Holtom, B. 2004. The effects of job embeddedness on organizational citizenship, job performance, volitional absences, and voluntary turnover. Academy of Management Journal, 47(5): 711-722.

March, J. 1994. A primer on decision making: How decisions happen. NY: Free Press.

Mesmer-Magnus, J., \& Viswesvaran, C. 2006. How family-friendly work environments affect work/family conflict: A meta-analytic examination. Journal of Labor Research, 4: 555574.

McDonald, P., Brown, K., \& Bradley, L. 2005. Explanations for the provision-utilisation gap in work-life policy. Women in Management Review, 20(1): 37-55.

Neal, M., \& Hammer, L. 2007. Working couples caring for children and aging parents: Effects on work and well-being. Mahwah, NJ: Lawrence Erlbaum.

Poelmans, S. 2005. The decision process theory of work and family. In E. Kossek \& S. Lambert (Eds.), Managing work-life integration in organizations: Future directions for research and practice: 263-285. Mahwah NJ: Lawrence Erlbaum Associates.

Raghuram, S., \& Wiesenfeld, B. 2004. Work-nonwork conflict and job stress among virtual workers. Human Resource Management, 43: 259-277.

Ryan, A., \& Kossek, E. 2008. Work-life policy implementation: Breaking down or creating barriers to inclusiveness? Human Resource Management, 47(2): 295-310.

Saltzstein, A., Ting, Y., \& Saltzstein, G. 2001. Work-family balance and job satisfaction: The impact of family-friendly policies on attitudes of federal government employees. Public Administration Review, 61(4): 452-467.

Schieman, S., \& Young, M. 2010. Is there a downside to schedule control for the work-family interface? Journal of Family Issues. doi:10.1177/0192513X10361866.

Schooreel, T., \& Verbruggen, M. 2015. Use of family-friendly work arrangements and workfamily conflict: Crossover effects in dual-earner couples. Journal of Occupational Health Psychology, accepted.

Shockley, K., \& Allen, T. 2007. When flexibility helps: Another look at the availability of flexible work arrangements and work-family conflict. Journal of Vocational Behavior, 71(3): 479-493. 
Shockley, K., \& Allen, T. 2010. Investigating the missing link in flexible work arrangement utilization: An individual difference perspective. Journal of Vocational Behavior, 76(1): 131-142.

Spector, P. 1986. Perceived control by employees: A meta-analysis of studies concerning autonomy and participation at work. Human relations, 39(11): 1005-1016.

Standen, P., Daniels, K., \& Lamond, D. 1999. The home as a workplace: Work-family interaction and psychological well-being in telework. Journal of Occupational Health Psychology, 4(4): 368-381.

Tabachnick, B., \& Fidell, L. 2001. Using multivariate statistics (4th ed.). Boston, MA: Allyn and Bacon.

Ten Brummelhuis, L., \& Van der Lippe, T. 2010. Effective work-life balance support for various household structures. Human Resource Management, 49, 175-195.

Thompson, C., Beauvais, L., \& Lyness, K. 1999. When work-family benefits are not enough: The influence of work-family culture on benefit utilization, organizational attachment, and work-family conflict. Journal of Vocational Behavior, 54(3): 392-415.

Thompson, C., \& Prottas, D. 2006. Relationships among organizational family support, job autonomy, perceived control, and employee well-being. Journal of Occupational Health Psychology, 11(1): 100-118.

Thornthwaite, L. 2004. Working time and work-family balance: A review of employees' preferences. Asia Pacific Journal of Human Resources, 42(2): 166-184.

Van De Voorde, K., Paauwe, J., \& Van Veldhoven, M. 2012. Employee well-being and the HRM-organizational performance relationship: A review of quantitative studies. International Journal of Management Reviews, 14(4): 391-407.

Versey, H. 2015. Managing work and family: Do control strategies help? Developmental Psychology, 51(11): 1672-1681

Zabalza, A., Pissarides, C., \& Barton, M. 1980. Social security and the choice between fulltime work, part-time work and retirement. Journal of Public Economics, 14(2): 245276. 


\section{LIST OF TABLES AND FIGURES}

\section{FIGURE 1}

\section{Hypothetical Relationships Between Predictors and Employee Outcomes ${ }^{\mathrm{a}}$}

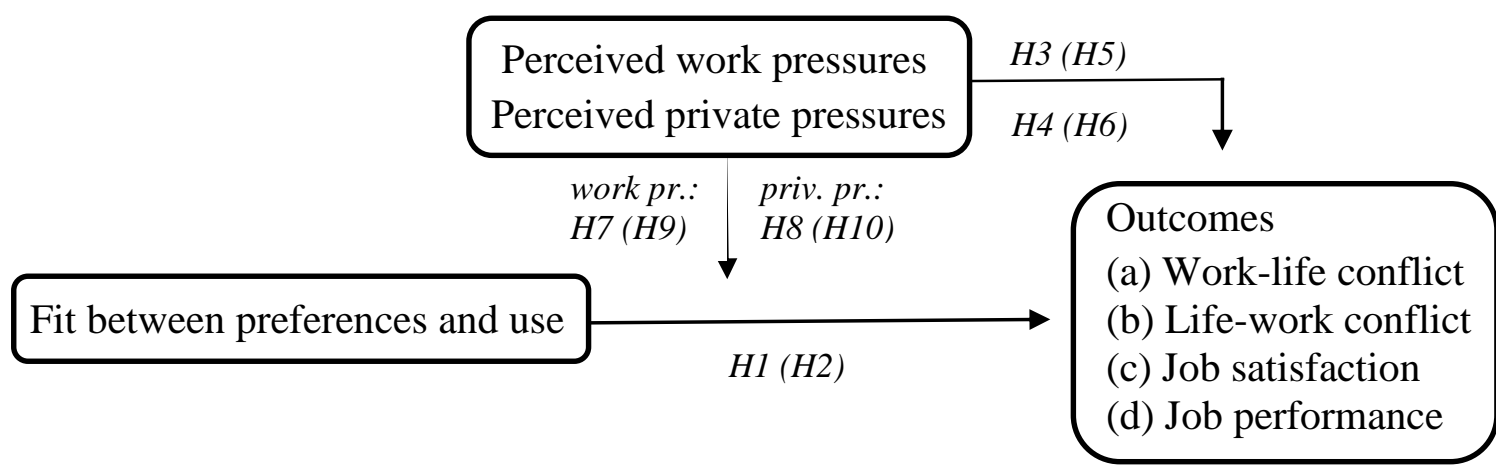

${ }^{a}$ Effects are studied separately for home-based telework and part-time work. Hypotheses for telework are shown without parentheses; hypotheses for part-time work are shown between parentheses.

\section{FIGURE 2}

\section{Graphical Presentation of Significant Interactions ${ }^{\mathrm{a}}$}

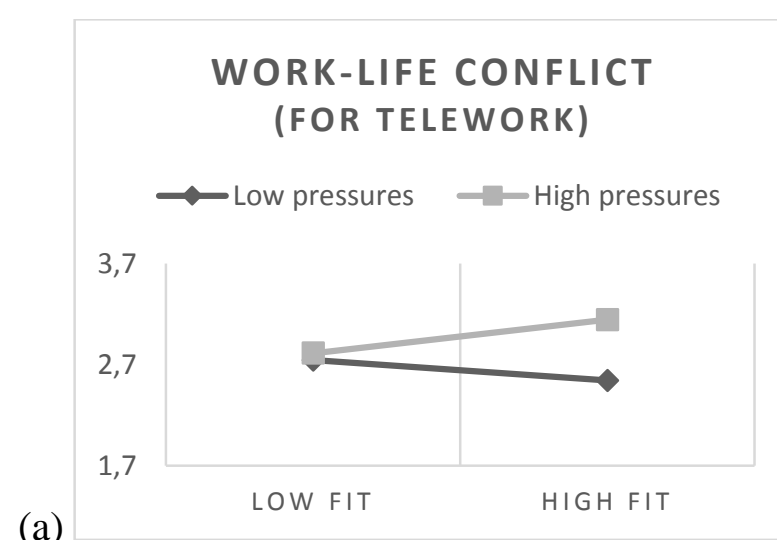

(b)

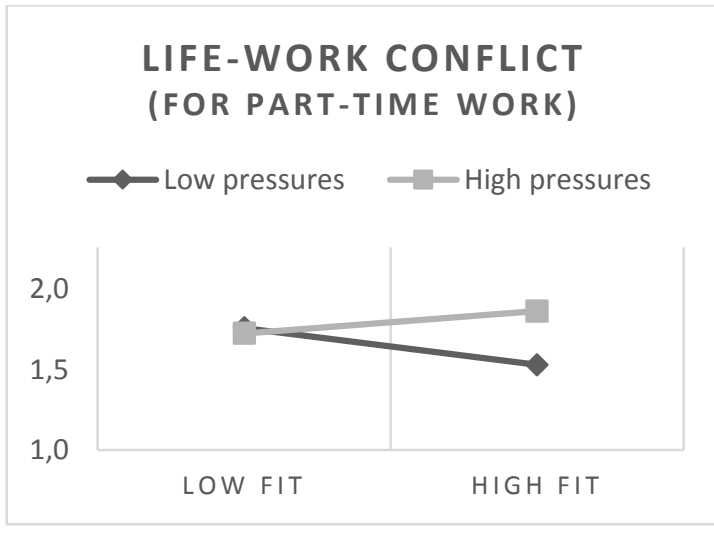

${ }^{a}$ Interactions between fit and perceived work pressures on (a) work-life conflict $(M=2.74, S D=$ 1) for home-based telework, and on (b) life-work conflict $(M=1.67, S D=0.63)$ for part-time work. Scale minimum and scale maximum of Y-axes are calculated $M-S D$ and $M+S D$ respectively. The graphical distinction of low perceived pressures versus high perceived pressures and low fit versus high fit is made based upon a median split of perceived pressures and of fit. 
TABLE 1

Basic Descriptives, Reliability Coefficients and Correlations of all Study Variables ${ }^{\mathrm{a}}$

\begin{tabular}{|c|c|c|c|c|c|c|c|c|c|c|c|c|c|c|c|c|c|}
\hline Variable & $\mathbf{M}$ & SD & 1 & 2 & 3 & 4 & 5 & 6 & 7 & 8 & 9 & 10 & 11 & 12 & 13 & 14 & 15 \\
\hline$\overline{1 . \text { Fit (telework) }}$ & 3.86 & 1.21 & .93 & & & & & & & & & & & & & & \\
\hline 2. Fit (part-time) & 4.06 & 0.99 & .13 & .89 & & & & & & & & & & & & & \\
\hline 3. Work pressures (telework) & 2.46 & 3.36 & -.41 & -.13 & - & & & & & & & & & & & & \\
\hline 4. Private pressures (telework) & 1.24 & 2.54 & -.22 & .03 & .36 & - & & & & & & & & & & & \\
\hline 5. Work pressures (part-time) & 1.19 & 2.75 & -.03 & -.50 & .19 & .06 & - & & & & & & & & & & \\
\hline 6. Private pressures (part-time) & 1.54 & 2.71 & -.11 & -.30 & .11 & .17 & .16 & - & & & & & & & & & \\
\hline 7. Work-life conflict & 2.74 & 1.00 & -.06 & -.24 & .21 & .02 & .21 & .17 & .90 & & & & & & & & \\
\hline 8. Life-work conflict & 1.67 & 0.63 & -.06 & -.13 & .16 & .26 & .09 & .24 & .35 & .84 & & & & & & & \\
\hline 9. Job satisfaction & 4.38 & 0.64 & .08 & .20 & -.17 & -.05 & -.15 & -.16 & -.35 & -.26 & .85 & & & & & & \\
\hline 10. Job performance & 4.38 & 0.52 & -.04 & .02 & -.07 & -.10 & -.03 & -.05 & -.30 & -.35 & .36 & .79 & & & & & \\
\hline 11. Use of telework & 0.57 & 0.50 & .64 & .02 & -.12 & -.02 & .06 & .09 & .25 & .13 & -.08 & -.12 & 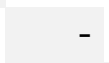 & & & & \\
\hline 12. Use of part-time work & 0.25 & 0.43 & -.16 & -.16 & .07 & .14 & .26 & .07 & -.15 & -.03 & .02 & .17 & -.16 & - & & & \\
\hline 13. Gender & 0.41 & 0.49 & .02 & .00 & -.13 & -.02 & -.12 & -.01 & .13 & .10 & -.13 & -.09 & .01 & -.18 & - & & \\
\hline 14. Age & 39.64 & 11.38 & -.05 & -.14 & -.04 & -.06 & .05 & .01 & -.02 & -.06 & -.10 & .14 & -.10 & .25 & .21 & - & \\
\hline 15. Number of children & 1.14 & 1.14 & -.02 & -.22 & .03 & .04 & .20 & .12 & .05 & .10 & .01 & .10 & .04 & .20 & .09 & .33 & \\
\hline
\end{tabular}

${ }^{a} N=382$. Reliability coefficients are presented on the diagonal axis. Correlations greater than $|.13|$ are significant at $p<.01$. Correlations greater than $|.10|$ are significant at $p<.05$. Correlations greater than $|.08|$ are significant at $p<.10$. Gender: $0=$ men, $1=$ women. 


\section{TABLE 2}

Standardized Regression Coefficients ( $\beta$ 's) for Effects of Controls, of Fit, of Work Pressures and Private Pressures, and of Interaction Effects for Home-Based Telework ${ }^{\mathrm{a}}$

\begin{tabular}{|c|c|c|c|c|c|c|c|c|c|c|c|c|}
\hline & \multicolumn{12}{|c|}{ Dependent variables } \\
\hline & \multicolumn{3}{|c|}{ Work-life conflict } & \multicolumn{3}{|c|}{ Life-work conflict } & \multicolumn{3}{|c|}{ Job satisfaction } & \multicolumn{3}{|c|}{ Job performance } \\
\hline & Step 1 & Step 2 & Step 3 & Step 1 & Step 2 & Step 3 & Step 1 & Step 2 & Step 3 & Step 1 & Step 2 & Step 3 \\
\hline Gender & $0.12 *$ & $0.14 * *$ & $0.15^{* *}$ & 0.08 & $0.10+$ & $0.09+$ & -0.07 & -0.09 & $-0.09+$ & -0.09 & $-0.10+$ & $-0.10+$ \\
\hline Age & -0.07 & -0.05 & -0.07 & $-0.13 *$ & $-0.10+$ & $-0.10+$ & -0.02 & -0.04 & -0.03 & 0.09 & 0.07 & 0.08 \\
\hline Children & $0.10+$ & 0.06 & 0.07 & $0.16^{* *}$ & $0.12 *$ & $0.13 *$ & 0.02 & 0.04 & 0.04 & $0.11+$ & $0.12 *$ & $0.12+$ \\
\hline Use & $0.21 * *$ & $0.44 * *$ & $0.44 * *$ & $0.12 *$ & $0.24 * *$ & $0.24 * *$ & -0.08 & $-0.22 * *$ & $-0.22 * *$ & $-0.14^{*}$ & $-0.17 *$ & $-0.17+$ \\
\hline Fit & & $-0.32 * *$ & $-0.46^{* *}$ & & $-0.16^{*}$ & $-0.23 *$ & & $0.18^{*}$ & $0.26^{* *}$ & & 0.03 & 0.08 \\
\hline Work press. & & $0.19 * *$ & -0.25 & & 0.07 & -0.07 & & $-0.15^{*}$ & 0.12 & & -0.08 & 0.11 \\
\hline Private press. & & $-0.11 *$ & 0.04 & & $0.19 * *$ & 0.07 & & 0.03 & -0.06 & & -0.07 & -0.15 \\
\hline Fit x work pr. & & & $0.44 * *$ & & & 0.13 & & & $-0.27+$ & & & -0.19 \\
\hline Fit x priv. pr. & & & -0.18 & & & 0.12 & & & 0.12 & & & 0.09 \\
\hline $\mathrm{R}^{2}$ & $0.07 * *$ & $0.19^{* *}$ & $0.21 * *$ & $0.05 * *$ & $0.14 * *$ & $0.14 * *$ & 0.01 & $0.07 * *$ & $0.07^{* *}$ & $0.05^{* *}$ & $0.07 * *$ & $0.07 *$ \\
\hline$\Delta \mathrm{R}^{2}$ & $0.07 * *$ & $0.12 * *$ & $0.02 * *$ & $0.05 * *$ & $0.08 * *$ & 0.00 & 0.01 & $0.05 * *$ & 0.01 & $0.05^{* *}$ & 0.02 & 0.00 \\
\hline $\mathrm{F}$ & $6.37 * *$ & $10.62 * *$ & $9.51 * *$ & $4.60 * *$ & $7.17 * *$ & $5.77 * *$ & 0.98 & $3.20 * *$ & $2.85^{* *}$ & $4.16^{* *}$ & $3.26^{* *}$ & $2.71 *$ \\
\hline
\end{tabular}

${ }^{\text {a }} N=382 . * * p<.01 * p<.05+p<.10$. Age is mean-centered. The most parsimonious models are marked.

TABLE 3

Standardized Regression Coefficients ( $\beta$ 's) for Effects of Controls, of Fit, of Work Pressures and Private Pressures, and of an Interaction Effect for Part-Time Work ${ }^{\mathrm{a}}$

\begin{tabular}{|c|c|c|c|c|c|c|c|c|c|c|c|c|}
\hline & \multicolumn{12}{|c|}{ Dependent variables } \\
\hline & \multicolumn{3}{|c|}{ Work-life conflict } & \multicolumn{3}{|c|}{ Life-work conflict } & \multicolumn{3}{|c|}{ Job satisfaction } & \multicolumn{3}{|c|}{ Job performance } \\
\hline & Step 1 & Step 2 & Step 3 & Step 1 & Step 2 & Step 3 & Step 1 & Step 2 & Step 3 & Step 1 & Step 2 & Step 3 \\
\hline Gender & $0.11+$ & $0.12 *$ & $0.12 *$ & $0.11+$ & 0.11 & $0.11 *$ & -0.06 & -0.07 & -0.07 & $-0.09+$ & $-0.10+$ & $-0.10+$ \\
\hline Age & -0.05 & -0.04 & -0.03 & $-0.16^{* *}$ & $-0.15^{* *}$ & $-0.13^{*}$ & -0.06 & -0.07 & -0.07 & $0.15^{*}$ & $0.14 *$ & $0.13^{*}$ \\
\hline Children & 0.08 & 0.01 & 0.01 & $0.10+$ & 0.06 & 0.04 & 0.06 & $0.11 *$ & $0.11+$ & 0.06 & 0.08 & 0.09 \\
\hline Use & $-0.11+$ & $-0.18 * *$ & $-0.18^{* *}$ & 0.04 & 0.01 & -0.03 & -0.02 & 0.03 & 0.02 & 0.06 & 0.08 & 0.10 \\
\hline Fit & & $-0.13^{*}$ & $-0.15^{*}$ & & $-0.03 *$ & -0.10 & & $0.12+$ & 0.11 & & -0.01 & 0.02 \\
\hline Work press. & & $0.18 * *$ & 0.12 & & 0.06 & -0.20 & & -0.10 & -0.13 & & -0.09 & 0.02 \\
\hline Priv. press. & & $0.11 *$ & $0.11 *$ & & $0.22 * *$ & $0.22 * *$ & & $-0.13 *$ & $-0.13^{*}$ & & -0.06 & -0.06 \\
\hline Fit x work pr. & & & 0.06 & & & $0.26 *$ & & & 0.03 & & & -0.11 \\
\hline $\mathrm{R}^{2}$ & $0.03 *$ & $0.12^{* *}$ & $0.12 * *$ & $0.03 *$ & $0.09^{* *}$ & $0.10 * *$ & 0.01 & $0.07 * *$ & $0.07 * *$ & $0.05^{* *}$ & $0.06 * *$ & $0.06^{* *}$ \\
\hline$\Delta \mathrm{R}^{2}$ & $0.03 *$ & $0.09 * *$ & 0.00 & $0.03+$ & $0.06^{* *}$ & $0.01+$ & 0.01 & $0.06^{* *}$ & 0.00 & $0.05^{* *}$ & 0.01 & 0.00 \\
\hline $\mathrm{F}$ & $2.81 *$ & $6.49 * *$ & $5.69^{* *}$ & $2.39 *$ & $4.47 * *$ & $4.40 * *$ & 0.66 & $3.41^{* *}$ & $2.99 * *$ & $4.10 * *$ & $2.90 * *$ & $2.62^{* *}$ \\
\hline
\end{tabular}

${ }^{\mathrm{a}} N=382 . * * p<.01 * p<.05+p<.10$. Age is mean-centered. The most parsimonious models are marked. 
TABLE 4

Overview of Standardized Regression Coefficients ( $\beta$ 's) of Study Variables in the Most Parsimonious Models ${ }^{\text {a }}$

\begin{tabular}{|c|c|c|c|c|}
\hline & $\begin{array}{l}\text { Work-life } \\
\text { conflict }(a)\end{array}$ & $\begin{array}{l}\text { Life-work } \\
\text { conflict }(b)\end{array}$ & $\begin{array}{l}\text { Job satis- } \\
\text { faction }(c)\end{array}$ & $\begin{array}{c}\text { Job per- } \\
\text { formance }(d)\end{array}$ \\
\hline \multicolumn{5}{|l|}{ Fit } \\
\hline Telework $(H 1)$ & $-0.46^{* *}$ & $-0.16^{*}$ & $0.18^{*}$ & model $n s$ \\
\hline Part-time work $(H 2)$ & $-0.13 *$ & -0.10 & $0.12+$ & model $n s$ \\
\hline \multicolumn{5}{|l|}{ Pressures } \\
\hline \multicolumn{5}{|l|}{ Telework } \\
\hline Work pressures $(H 3)$ & -0.25 & 0.07 & $-0.15^{*}$ & model ns \\
\hline Private pressures $(H 4)$ & $-0.11^{*}$ & $0.19 * *$ & 0.03 & model ns \\
\hline \multicolumn{5}{|l|}{ Part-time work } \\
\hline Work pressures (H5) & $0.18 * *$ & -0.20 & -0.10 & model ns \\
\hline Private pressures $(H 6)$ & $0.11 *$ & $0.22 * *$ & $-0.13^{*}$ & model ns \\
\hline \multicolumn{5}{|l|}{ Fit $x$ pressures } \\
\hline \multicolumn{5}{|l|}{ Telework } \\
\hline Fit $\mathrm{x}$ work pressures $(H 7)$ & $0.44 * *$ & model ns & model ns & model ns \\
\hline Fit $\mathrm{x}$ private pressures $(H 8)$ & -0.18 & model ns & model ns & model ns \\
\hline \multicolumn{5}{|l|}{ Part-time work } \\
\hline Fit $\mathrm{x}$ work pressures $(\mathrm{H} 9)$ & model $n s$ & $0.26 *$ & model $n s$ & model $n s$ \\
\hline Fit $\mathrm{x}$ private pressures $(\mathrm{H} 1 \mathrm{O})$ & multicoll & multicoll & multicoll & multicoll \\
\hline
\end{tabular}

${ }^{\mathrm{a}} N=382 . * * p<.01 * p<.05+p<.10$. Model $n s=$ variables only present in nonsignificant models. Multicoll $=$ effect not analyzed because of multicollinearity. 